This item was submitted to Loughborough's Research Repository by the author.

Items in Figshare are protected by copyright, with all rights reserved, unless otherwise indicated.

\title{
Ethno-cultural diversity and the limits of the inclusive nation
}

PLEASE CITE THE PUBLISHED VERSION

https://doi.org/10.1080/1070289X.2018.1494968

PUBLISHER

(C) Taylor \& Francis (Routledge)

VERSION

AM (Accepted Manuscript)

PUBLISHER STATEMENT

This is an Accepted Manuscript of an article published by Taylor \& Francis in Identities on $30 \mathrm{Jul} 2018$, available online: https://doi.org/10.1080/1070289X.2018.1494968

\section{LICENCE}

CC BY-NC-ND 4.0

\section{REPOSITORY RECORD}

Antonsich, Marco, and Enza Roberta Petrillo. 2018. "Ethno-cultural Diversity and the Limits of the Inclusive Nation". figshare. https://hdl.handle.net/2134/33802. 


\title{
Ethno-cultural diversity and the limits of the inclusive nation
}

Marco Antonsich, Department of Geography, Loughborough University, Loughborough LE11 3TU, United Kingdom, Email: m.antonsich@lboro.ac.uk

Enza Roberta Petrillo, Eurosapienza Research Center. University of Rome 'La Sapienza', Via del Castro Laurenziano 9, 00161 Roma, Italy, Email: enzaroberta.petrillo@uniroma1.it

\begin{abstract}
:
Migration is often said, in the public discourse, to pose a threat to the nation. Yet, Western societies are undergoing an irreversible demographic change spurred in great part by international migration. Thus, the question about how to reconcile nation and diversity remains of crucial importance for many countries. By focusing on the case of Italy, the article attends to this issue, by exploring the response of leftist political parties. We analyse parliamentary debates and laws related to immigration and integration issues (1986-2014), focusing specifically on the TurcoNapolitano Law (1998), possibly the most progressive legislative attempt at incorporating migrants into the Italian nation. Our analysis shows a clear incongruence between the pluralist rhetoric of the political left and its legislative acts on migrants' national incorporation. This finding is used to reflect on the limits and possibilities of the very idea of inclusive nation in the age of migration.
\end{abstract}

Key-words: nation, migration, diversity, inclusion, integration, Italy 


\section{Introduction}

Nation and ethno-cultural diversity are usually posited as two opposites (Antonsich and Matejskova 2015a). As one of the main embodiments of this diversity, immigrants are generally said - in common discourse - to unsettle the isomorphism between people and nation (Wimmer and Glick Schiller 2002, 309), to introduce a substantial dissonance into the idea of the nationstate (Favell 2001, 122), to pose a threat to national culture (Vertovec 2011, 241) and to challenge an understanding of national territories as coherently defined and homogeneous spaces (Jones and Merriman 2012, 938). This seems particularly true nowadays in Europe, where political actors have long sentenced multiculturalism to death, at least rhetorically (Vertovec and Wessendorf 2010; Banting and Kymlicka 2012; Modood 2013). And yet, Western societies are undergoing what Alba and Foner (2014) call 'a transition to diversity', i.e. an irreversible demographic change spurred in great part by international migration. Thus, the question about how to generate inclusive nations remains of crucial importance for many Western democracies.

To address this challenge, Western European countries have moved away from an ethno-cultural idea of national membership to a civic one, centred on principles of liberal universalism (Joppke 2007). This 'liberal convergence', however, has not gone unquestioned. Scholars have noted that this process of thinning down of the nation is only one part of the story. Parallel to the heralding of liberal citizenship as the binding principle of increasingly diverse societies, a series of integration measures have indeed been introduced (e.g., language and civilization courses) aimed at reaffirming the overlap between the majority culture and the national culture (Goodman 2010).

The aim of this article is to explore how nation and diversity are jointly mobilized in political discourses and policies in order to more fully evaluate the possibilities and limits of the idea of inclusive nation, i.e. a nation which embraces the ethno-cultural and religious diversity of its 
population. The goal is not to show, like other authors have already done (Kostakopoulou 2010; Mouritsen 2008; Jensen 2014), how liberal democratic values are strategically deployed to reaffirm the hegemonic power of the ethno-cultural majority over the symbolic and material boundaries of the nation. We plan instead to follow the idea of an inclusive nation in the passage from its formulation in political speeches to its implementation in legislative acts in order to reflect on the obstacles that such an idea encounters in its actualization at the institutional level. To this end, the article focuses on Italy and analyses the parliamentary debate associated with the TurcoNapolitano Law (1998). Although located back in time, we would argue that this has been the most progressive legislative attempt at incorporating immigrants into the Italian nation since the first immigration law was passed in 1986 (Allievi 2014). Subsequent governments, also centre-left ones, have instead adopted stricter policies (Gargiulo 2014a).

Before delving into the empirical materials, the article first discusses the notion of inclusive nation as it emerges in three major strands of scholarly literature (civic, liberal, and multicultural nationalism). It then introduces and analyses the case of Italy and its immigration laws. In the conclusion, we build on the insights of the Italian case study to reflect more broadly on the possibilities and limits of an inclusive nation.

\section{Thinking of inclusive nation}

The analytical framework used in this study relies on three major scholarly approaches which have theorized the links between nation and diversity: civic, liberal, and multicultural nationalism. The notion of 'civic' nation has emerged in the distinction with the 'ethnic' nation - a distinction originally introduced by Kohn (1945) to explain the different historical origin of nationalism in the West compared to the rest of the world. While the civic nation stands for a political-legal community of citizens sharing a liberal, civic culture, the ethnic nation stands for a community of 
common descent (Smith 1991). For this reason, while the civic nation is supposedly liberal, voluntarist, universalist, and inclusive, the ethnic nation is casted as illiberal, ascriptive, particularistic, and exclusive (Brubaker 1999, 56).

However contentious this distinction might be - since all civic nationalisms contain elements of an ethnic core (Kymlicka 2001; Brubaker 1999; Calhoun 2007) - it features nevertheless in Joppke's (2008) notion of 'liberal convergence'. The main point of this thesis is that Western European societies have experienced a de-ethnicization process (Joppke and Morawska 2003); they have increasingly turned civic, heralding a thin and universalistic citizenship, informed by liberal political culture (Joppke 2010). Within this new civic model, as Baumeister $(2007,484)$ observes, "citizens need only be socialized into a common political culture based upon standard liberal constitutional principles"; they have to become "good liberals rather than good Danes, Frenchmen or Brits" (Gustavsson 2015). This is why Joppke reads the civic model as a form of constitutional patriotism à la Habermas. For this latter philosopher, the only way multicultural societies can be hold together is through the sharing of a common political culture (Habermas 1998, 118). This implies the detachment of the majority culture from the wider political culture shared by all citizens (Habermas 2001, 160). The liberal democratic principles enshrined in the constitution are the only guide for regulating interactions among a multicultural population. In this sense, Habermas labels his model 'post-national', since it moves away from nationalist ideas of pre-political communities based on common descent, privileging instead a cosmopolitan idea of political communities constituted around the sharing of liberal democratic principles. Contra to those who accuse this new post-national formation as being insufficient to give a polity a distinctive identity (Joppke 2008), Habermas maintains that any universalism finds its realization only through the particular history, traditions and life forms of a national culture (Pensky 2001). In this sense, a national culture continues to exist, but it is rewritten in political terms, as a way to make it more inclusive. 
This liberal convergence onto a civic model has not gone without criticism. Besides universalistic membership criteria, this model has indeed been characterised by an integrationist thrust articulated around courses, tests and contracts aimed at incorporating immigrants into the existing cultural values of the majority group (Goodman 2010). This reflects the demand that the majority society places on immigrants to be knowledgeable in the national language, history, values and traditions in order to be admitted, reside or naturalize in the receiving country. For this reason, some authors have questioned the 'liberal' character of civic integration, suggesting that it instead reinforces the monopoly of the majority group over the symbolic boundaries and meanings of the national culture (Kostakopoulou 2010; Kymlicka 2015). In other words, far from turning civic, the nation still remains an ethno-cultural construct.

It should be said, though, that the persistence of the majority culture in shaping the identity of the nation is not always criticized in the literature. For instance, liberal nationalism aims to generate an inclusive nation by explicitly maintaining a core of national principles, values, histories and language, while simultaneously accommodating the diversity of the minority groups (Kymlicka 2002). While civic nationalism à la Habermas erases the culture of 'the people' from the public sphere, which is then reframed in mere political terms, liberal nationalism preserves this culture, but tries to make it more inclusive by playing down the ethnic, religious and ways of life of the majority group and by supplementing minorities with special rights to enhance their public participation (Kymlicka 2001). However, in the readings of Kymlicka and Miller - two well-known liberal nationalists - diversity remains framed as a problem, something to be fixed by accommodating its special needs within a liberal framework (Kymlicka 2001) or by relegating it into the private sphere (Miller 2000, 122 137). Thus, despite its aim of de-ethnicizing the nation, liberal nationalism still reproduces a 'we'/'them' logic. This is even more apparent in its Quebecois 
'intercultural' variation, which although open to a re-writing of the nation, it clearly supports the primacy of the majority culture (Bouchard 2011).

If civic nationalism moves away from (national) culture and liberal nationalism tries to thin it down, another normative discourse, namely political multiculturalism or multicultural nationalism, adopts instead a different strategy to generate inclusive nations. Its aim is indeed not 'to take off', but to add diversity, so to generate a national society made of a plurality of communities, each of them placed on an equal foot (Parekh 2000; Modood 2007). In this sense, political multiculturalism can be read as a normative project aimed at pluralizing the nation.

In what follows, after presenting the case study, we read the Turco-Napolitano Law against the above three theoretical approaches and assess its implementation as a way to reflect on the limits and possibilities of the inclusive nation.

\section{The case study: Italy}

Italy is a typical country of the so-called 'Mediterranean model of immigration' (King and Black 1997). Countries which fit this model are characterised, among others, by two major factors: the transformation from a country of emigration to a country of immigration, with the increase of migrant population in a relatively short time period; and a public ill-prepared for the settlement of immigrants. Although statistically the turning point was in 1973 , the first considerable inflow took place between 1984 and 1989 (Bonifazi et al. 2009). Besides being a relatively recent phenomenon, immigration to Italy has also been a relatively rapid one. On 1 January 2003, foreign nationals amounted to $1,549,373$ or $2.7 \%$ of the total population. More than a decade later, on 1 January 2017 , this figure was up to $5,047,028$ or $8.33 \%$ of the total population (ISTAT http://demo.istat.it/strasa2017/index.html). 
The novelty and rapidity of this phenomenon partly explains the weakness of Italy's immigration and integration legal framework (Allievi 2014; Pugliese 2002; Pastore 2004). From the mid-1980s onwards, immigration laws were introduced, responding more to a sense of 'emergency' (the perception of being 'invaded') than to a coherent immigration and integration policy. In 1986, the Parliament, dominated by a centre-left majority, passed the first immigration act (Law 943/1986), which regularized 118,700 immigrants already living in Italy, introduced annual migratory quota to match the labour market needs, and extended socio-economic rights to the immigrant workers in line with the ILO Convention 143/1975. Four years later, just before the 'Albanian crisis' of 1991 which acted as a watershed in Italy's collective memory regarding immigration (Garau 2014) - the Parliament, led by another centre-left majority, approved the so-called Martelli Law (39/1990). Like the previous act, the new law passed an amnesty $(217,700$ immigrants were regularized), introduced new annual quotas tied to "the real opportunities to integrate immigrants in the Italian society" (art. 2.4b), and confirmed equal social rights for immigrants. Critics (Zincone 2006) have regarded both laws as mainly driven by an instrumental or functionalist logic, which considers immigrants only as a workforce, failing to effectively address the problem of their long-term social and cultural integration.

The first clear departure from this approach was the so-called Turco-Napolitano Law (40/1998), equally approved in 1998 by a centre-left majority. This law can be considered as the most articulated attempt to look at immigrants not merely through economic or security lenses, but also in terms of new citizens or 'new Italians' (Turco and Tavella 2005). For this reason, the present article will scrutinize in depth both the parliamentary debate and the legal content of Law 40/1998.

This law was also the last immigration law passed by a centre-left majority. In 2001, Berlusconi, leading a centre-right majority, came to power and, apart from 2006-2008, ruled Italy until 
November 2011. During this period, two important legislative acts were passed: the Bossi-Fini Law (189/2002) and the so-called Pacchetto Sicurezza (Security Package). Law 189/2002 - the law which still today regulates immigration to Italy - restricted the Turco Napolitano Law, imposing further constraints on entry, tightening the conditions for stay, making family reunification more difficult, and introducing harsher measures for undocumented immigrants (Zincone 1998). The Pacchetto Sicurezza - formed by two main laws (125/2008 and 94/2009) - further sanctioned the representation of immigrants as potential criminals and, accordingly, created ronde (patrols of voluntary citizens) to locally monitor public order, increased from 60 to 180 days the maximum period of detention in the Centri di Identificazione ed Espulsione $(\mathrm{CIE})^{1}$, introduced the 'integration agreement' (law 94/2008, art 4-bis) ${ }^{2}$, and enlarged the number of crimes for which a permesso di soggiorno (residency permit) could be refused. Significantly enough, the successive governments led by Monti, Letta and Renzi, all based on the centre-left Democratic Party (PD), have not rebuffed this restrictive legislation.

Data used in this study come from an extensive archival research on parliamentary debates, bills and laws produced from 1986 until 2014, both in the Camera (Lower House) and Senato (Upper House). A series of key words were used to search electronically their databases. ${ }^{3}$ In addition, we also interviewed relevant ministerial officers, representatives of the political parties responsible for immigration and key-political figures associated with major immigration laws, including the Turco-Napolitano Law. A total of nineteen in-person, semi-structured individual interviews were administered (16 men, 3 women, aged from 32 to 69). These interviews, which were transcribed verbatim, served to better understand the political dynamics behind relevant laws. All data were collected in Italian (translations are by the authors) and coded using the same key-words used for the archival search. 
A final observation applies. Italy has often been portrayed as a failed or unaccomplished nation (Graziano 2010), characterised by its citizens' fragile sense of national identity (Galli della Loggia 1996; Bedani and Haddock 2000; Patriarca 2010). Among the most common reasons mentioned are the weakness of the state (Gentile 2010), the North-South divide (Schneider 1998), and poor social capital and civic spirit (Putnam 1993). However, when asked about national pride, Italians usually show a percentage higher than the European average (Antonsich 2009). The main concern of this article, nevertheless, is not to assess where Italy stands on a continuum between 'weak' and 'strong' national identity. This would indeed reproduce a substantialist idea of nation which clashes against the discursivist approach adopted in this study (see (Brubaker 2006)). Instead, we are interested in how an idea of inclusive nation moves from the rhetorical level to its legislative implementation. It is by illuminating the short circuits encountered in this implementation that we wish to reflect on the limits and possibilities for such an idea to be actualized.

\section{Talking inclusive nation}

The Turco-Napolitano Law (40/1998) was passed by a parliamentary majority composed by the Partito Democratico della Sinistra (PDS) (the major party of the centre-left coalition, closely aligned to social-democratic positions), the Partito Popolare Italiano (PPI) (a centre-left Christian democratic formation), the radical-left Partito della Rifondazione Comunista (PRC), and various leftist parties organized under the parliamentary group called Sinistra Democratica (SD).

During the parliamentary debate on this law, two opposite views of nation clearly emerged. On the one hand, parties leaning towards the political right read immigration in threatening terms, calling for the defence of the nation against a demographic, economic, and identity menace. On the other hand, parties leaning towards the political left welcomed the demographic change associated with immigration and although they acknowledged the problems this transformation 
might generate, they also looked at it with a sense of historical ineluctability, believing that societies were doomed to become ethno-culturally diverse. It is on the speeches by the representatives of these latter parties that this section focuses.

If we use the theoretical tripartite view presented above (civic, liberal, and multicultural nation), it is fair to say that most of these speeches reflected a civic understanding of nation. Within this perspective, a common reference was to the Constitution and in particular to its art. 2 ("The Republic recognises and guarantees the inviolable rights of the person ...") and art. 3 ("All citizens have equal social dignity and are equal before the law, without distinction of sex, race, language, religion, political opinion, personal and social conditions"). These legal principles were for instance echoed in the following terms by a leading figure of the PDS and chair of the Constitutional Affairs Committee, Russo Jervolino (Camera, 30/09/1997: 33):

"[Immigration] is an unstoppable reality which in the future will intensify even more. The choice, then, is twofold, because it is about deciding whether we want to live this reality as a threat or as a positive chance. The choice is also whether we want to be coherent with the respect of the rights of the person, with the principle of solidarity, with the values, in short, that the Constitution and the Universal Declaration of Human Rights put at the basis of the civic living together or will use this chance to forget about these rights".

The demographic change spurs a renovated civic thrust which has in the recognition of rights to immigrants a key factor in shaping Italy's future. While rightist parties lamented that the bill accorded "too many rights" to immigrants (Menia, Alleanza Nazionale, Camera, 30/09/1997: 49), the leftist majority stressed the opposite view:

"Right to work, right to health, but also right to family unity and to the protection of children; right to education and to public housing. It is on fundamental social rights that, in 
the whole Western world, the important and delicate question of immigrant integration is to be decided" (Olivo, SD, Camera, 30/09/1997: 41).

As part of this endeavour to generate a socially just and equal society, irrespective of the origins and legal status of its members, political participation in local elections was also central in the discussion. To support this point, Habermas and his post-national argument were also explicitly mentioned:

"The right to vote [...] is symbolically very important with regards to multicultural integration. The access to citizenship [...] finds its conclusive moment in the concession of the right to vote and to stand for election. I believe, indeed, that - as Habermas has also argued - the essence of citizenship should be found in the political rights of participation and communication" (Olivo, SD, Camera, 30/09/1997, 41).

Within the leftist camp, immigration was viewed as a chance to rethink Italian national society. As briefly put by Moroni (PRC, Camera, 23/10/1997, 57), "by this bill we decide not just the destiny of immigrants, but also the model of society we aspire to". Similarly, Gardiol (Verdi, Camera, 23/10/1997, 83) suggested that "immigration can be a chance for collective cultural growth", reaffirming the need to "re-elaborate the idea of citizenship, by separating it from the idea of nationality and incorporating those rights that a civic conscience considers as universal".

Contrary to their opponents, left and centre-left parties aspired to rewrite the meaning of the Italian nation and they saw in the civic transformation the way forward. Only rarely, instead, a multicultural reading came about during the parliamentary debate. Besides the brief reference heard above in the speech by Olivo, the theme also surfaced in the intervention by Corsini (SD, Camera, 19/11/1997, 121), who observed that "a politics of integration and acknowledgment of rights towards them [immigrants] is essential for a civil living-together, within a perspective of 
societal growth along multicultural lines". Similarly, the Interior undersecretary (Sinisi, PDS, Senato, 19/02/1998, 8), explaining to the Parliament the government's choice to use in the bill the term 'integration' rather than 'assimilation' (as instead requested by the political right), noted that this term was in line with "the ethic and cultural pluralism, as well as with the pluralism of ideas, which we essentially want to guarantee to our citizens, but also to all those who come and settle in our country". Yet, in both cases this multicultural or plural understanding of nation seems to merely describe a demographic change rather than to act as a normative argument. This point finds confirmation in the passage by Valetto Bitelli (PDS, Camera, 23/10/1997, 52):

\footnotetext{
"Whether we like it or not, a new society is emerging; a global, plural and multi-ethnic society, as 'the world is inside us' [...]. Thus, to win the challenge of globalization it is essential to offer our citizens a project for security and integration based on citizenship. If we build belonging to a civic community based on shared values and the effective representation of interests through democratic institution, a sense of mutual responsibility between state and citizens [...] then the new, the different could become less a source of fear and uncertainty".
}

In this case, the pluralization and multi-ethnic transformation of Italian society is not framed as a multiculturalist project, rather a civic one, based on the republican pact between the state and the citizen. Likewise, a liberal national understanding, reaffirming the cultural principles of the majority group, was heard only rarely from the centre-left coalition. During our interview with the ex-minister Turco (15/07/2015), after reaffirming that Law 40/1998 was "an excellent demonstration of reformist politics", she interestingly explained the notion of integration or, in her preferred terminology, convivenza (living-together) as follows: "I welcome you, but you respect my values and my rules. Yet, you don't only respect them, but you contribute to build them [...] it is about rewriting the values of the nation". This comment clearly reaffirms the 
primacy of the majority group and its values. Yet, it also opens to an inclusive nation beyond a civic framework, as newly shaped values would form the common glue to bring diverse people together, echoing the Quebecois variation of liberal nationalism (Bouchard 2011).

\section{Legislating on the inclusive nation}

If rhetorically the political left clearly rewrites the nation in response to a changing population, the analysis of Law 40/1998 returns a different picture. Before this law, Italian immigration policies focused mainly on border control and the regularization of undocumented immigrants (Finotelli and Sciortino 2009). Even if 'integration' was mentioned in these laws, it neither occupied a central position nor was defined in operational terms. As a consequence, local and regional governments adopted their own integration measures, such as courses of Italian language and provision of social housing (Gargiulo 2014b). It was within this context that Law 40/1998 was elaborated as "the first systematic immigration act, not conceived in emergency conditions and oriented to treat immigration as a permanent phenomenon" (Turco, interview, 15/07/2015 - see also (Gargiulo 2014b, 43)).

Drafted in close association with an 'advocacy group' formed by academics, civil servants and representatives of voluntary organizations, the Turco-Napolitano Law was the product of a compromise between a logic of securitization, embodied by the Minister of Interior (Napolitano), and a logic of inclusion, represented by the Minister of Social Affairs (Turco) (interview with a key officer at the former Social Affairs Ministry, 25/09/2015). In the words of Zincone (2000, 959-961), head of the Commission for the Policies of Immigrants' Integration created by the government soon after the approval of Law 40/1998, this law represented a model of 'reasonable integration', articulated around four dimensions: 1 ) interaction based on security; 2 ) integrity of human rights 
for illegal immigrants; 3) full integrity for legal immigrants; and 4) interaction based on pluralism and communication.

The structure of the law clearly reflected this model, with an additional economic dimension to pair with the security one. Following the general principles, security and work indeed substantiated Titles II and III of the law. The strengthening of border controls (art. 9), the fight against human trafficking (art. 10), new measures of expulsion (art. 11-14), and stricter entry and residency conditions (art. 4-7) were adopted not only in response to domestic public concerns, but also to reduce the anxiety of EU-partners after Italy joined the Schengen Agreement (Zincone 2006, 352). Yet, framing immigration first and foremost as a security problem had two important consequences for the production of an inclusive nation. First, it reinforced the identity function of the national boundary as the symbolic line dividing the space of the pre-existing nation from the 'other' space; second, and related to this point, it implicitly cast perennial suspicion on would-be 'new Italians', whose social status and moral standing would therefore always be different from Italians by birth and descent (Muehlebach 2012). In other words, it insinuated in the nation the same ethno-cultural bias which the civic rhetoric heard in the parliamentary debates aimed to displace.

Among the security measures adopted by the law, one in particular came under the spotlight and raised fierce criticism among the extreme-left: the creation of Centri di Permanenza Temporanei (Centres of Temporary Stay). The confinement of undocumented immigrants within these centres was limited to a maximum of 30 days (art. 12), with no provisions adopted after the expiration of this period. Yet, it is particularly relevant to note that it was a centre-left majority which first introduced what in the future, under centre-right governments, would more closely resemble detention camps, contributing to the criminalization of immigrants for their simple act of trespassing of the national boundary. 
An additional way to confirm the 'difference' of the immigrant from the rest of Italian citizens was the possibility for foreigners, even legally residing in the country, to be expelled if sentenced to three or more years of prison (art. 13). Interestingly, though, this provision did not apply in case the foreigner was living together with either a spouse or relatives of Italian nationality (art. 17.2c). Far from reconstituting a nation around a civic principle, this disposition was a clear reconfirmation of an exclusive nation framed around jus sanguinis, which only a few years earlier was also explicitly sanctioned in the new nationality law (1992), passed by a large cross-party majority (Pastore 2004).

The legalistic perspective, equating immigration with security, was also complemented with a functionalist approach, which regarded immigrants as mere workers (Zincone 2006). Law 40/1998, indeed, introduced an annual entry flow plan (art 3.4) linked to the country's economic needs. Like successive immigration laws passed by centre-right majorities, even the Turco-Napolitano law linked immigrants' right to sojourn to evidence of 'sufficient' income (art. 4.3). This evidence was also mandatory in case the immigrant, after five years of regular residence and in the absence of criminal records, wished to apply for a permit of permanent residence (carta di soggiorno) (art. 7). If immigrants were to lose their employed jobs, they had up to twelve months to find a new occupation; otherwise, they had to leave the country (art. 20.7). It is thus clear that, contrary to the rhetoric of citizenship based on universal rights, participation and communication heard in the parliamentary debate, the law sanctioned a conditional idea of citizenship, tied to immigrants' contribution to the national economy (Mezzadra and Neilson 2013). This view obviously resonates with the workfarist transformation of contemporary societies (Peck and Tickell 2002; Larner 2000; Jessop 1993) which affects each and every member, irrespective of their nationality and status. Yet, while a national remains a national even if they were to fall out of this workfarist logic, an immigrant would cease to exist within the national territory. In other words, the conjoined 
functioning of this workfarist/functional logic and the legalistic/securitarian logic within Law 40/1998 were clearly disavowing any reframing of the nation in civic, more inclusive terms.

A more pronounced attempt at looking at immigrants as persons rather than workers or potential criminals was contained both in the general principles (Title I) and in those norms presiding over family reunification, health care, education and housing (Titles IV and V). In outlining foreigners' rights and duties, art. 2 echoed the model suggested by the advocacy group and later adopted by the Commission for the Policies of Immigrants' Integration. It indeed extended the same civil rights of Italian citizens to documented foreigners (art. 2.2) and fundamental human rights only to undocumented immigrants (art. 2.1). Similarly, the right to preserve or restore family unity (art. 26-27), social care rights (art. 39), and full access to healthcare (art. 32) were exclusively reserved to documented immigrants holding a residence permit or waiting for its renewal, whereas undocumented immigrants could only benefit from urgent medical treatment (art. 33). Thus, while the call for the extension of rights to immigrants heard in the parliamentary debate did find legal recognition in Law 40/1998, its application was made contingent on the person being a 'legal' immigrant. In other words, the liberal principle of citizenship's universal rights around which to rewrite the nation in civic terms was confronted with differential citizenship (Cuttitta 2014) or civic stratification (Mottura and Rinaldini 2008), which in discriminating between nationals, legally residing foreigners and undocumented immigrants was preserving an ethno-centric form of nation.

The national divide also played out in regard to the right to vote in local elections for legally residing immigrants. As heard in the parliamentary debate, this was a key point to reframe national membership around the Habermasian notions of political participation and communication. On the one hand, Law 40/1998 did state the right and duty for the documented immigrant to participate to local public life (art. 2.3). Yet, the main channel to perform this 
right/duty, namely voting entitlement, was vehemently opposed by the rightist party Alleanza Nazionale (AN) and finally deemed unconstitutional by the legal office of the Camera (Zincone 2006). In the comments of the ex-Minister Turco: "Fini [leader of AN] and the centre-right demanded the scrapping of this norm, otherwise [the bill] would have been blocked. We at the Ministry of Social Affairs regarded the right to vote as a very innovative point, thus its scrapping was very painful" (Turco, individual interview, 15/07/2015).

One of the most receptive norms of the leftist rhetoric about re-writing the nation in more inclusive terms was art. 40. This norm called for regions, provinces and municipalities, alongside the state, to organize classes of immigrants' languages and cultures (art. 40.1a), to promote the cultural, recreational, social, economic, and religious expressions of immigrants (art. 40.1c), to allow legally residing foreigners to act as intercultural mediators between foreign citizens and the public administration (art. 40.1d), and to organize - for public officers - courses "inspired by criteria of coexistence within a multicultural society" aimed at preventing discriminatory, xenophobic or racist behaviour (art. 40.1e). Although this norm clearly acknowledged diversity as a feature of Italian society, its implementation largely failed. Law 40/1998, in fact, did not establish a national standard for protecting immigrants' language of origin or for teaching and certifying proficiency in Italian. It also lacked a national strategy for delivering on the mentioned multicultural activities, discharging large part of its implementation to local and regional administrations (interview with key officer, Ministry of Labour and Social Policy, 19/03/2015). The end result, as identified by Campomori and Caponio (2013), was the patchy implementation of integration measures across the national territory, spanning from assimilation to civic incorporation and structural precariousness. Although Law 40/1998 was largely inspired, in its Titles IV and V, by progressive local practices, it actually failed to feedback local territories with an effective national plan. 
A clear exception within the whole frame of Law 40/1998 were immigrant children, who enjoyed privileged legal protection, in line with the UN Convention on the Rights of the Child (1989), ratified by Italy in 1991. Among the special provisions for children (undocumented included) was full participation in compulsory education (art. 36.1). Interestingly, here the demographic change brought about by immigrant children was expressly acknowledged in terms of the cultural impact on the national society and, accordingly, art 36.3 introduced the notion of 'intercultural education': "The school community welcome linguistic and cultural differences as values upon which to base mutual respect, cultural exchange and tolerance; to this end, it promotes and favours initiatives aimed at welcoming [immigrant children], protecting [their] culture and language of origin, and realizing common intercultural activities". Yet, even in this case, the implementation of the norm was largely unattended and, in the absence of clear directives and allocated resources, each school was de facto left alone in dealing with intercultural education (interview with key officer, Ministry of Education, 20/07/2015).

\section{Conclusions}

During a recent workshop on the idea of inclusive nation organized by the Loughborough University Nationalism Network (LUNN), Billig (2017) observed that this very term, 'inclusive nation', sounds like an oxymoron. For this influential scholar, any nationalism is inherently exclusive. This is an important point that should not go forgotten. Yet, we would argue that it is equally important to investigate configurations of national inclusion, particularly in a context of increasing mobility of people. The nation in fact is not a historically stable, fixed, monolithic entity, given once for all, but keeps adjusting to ongoing processes of globalization, territorial reshuffling and demographic transformation (Biswas 2002; Antonsich and Matejskova 2015b). Within this 
context, it is therefore legitimate to explore how the nation is reframed to accommodate its increasingly diverse population.

The article has explored this issue by focusing, for the case of Italy, on the institutional response offered by the political left, traditionally regarded as more pro-immigrants than its political counterpart (Però 2005). By analysing both the parliamentary debate on and the content of Law 40/1998, we have shown the distance between an inclusive rhetoric - largely cast in civic terms and a legal framework which only to a limited extent reframes the nation in more inclusive terms. The obvious question is why this was the case.

Answering this question leads us to reflect on the limits and possibilities of the very idea of inclusive nation. Although the following considerations apply first and foremost to our chosen case study, we believe that they might also resonate with other geographical contexts (see, for instance, Mouritsen and Olsen (2013) for Denmark). A major obstacle in moving from a discursive to an actual level of national inclusivity can be identified in the short circuit between the ideological stance of the political left and the reality of governance. A passage from the interview with the ex-minister Turco should help illuminate this point:

"Immigration for me represented the toughest challenge of societal change. I mean, the toughest challenge for a leftist government which was called to realize the values of solidarity and welcoming [accoglienza]. [...] Then, the experience taught me that this was not enough. It was very tough. It was not sufficient to say 'we accept them'"' (Turco, individual interview, 15/07/2015)

Two major constrains - one international and one domestic - could be mentioned as a way to substantiate Turco's experience. Internationally, the concerns of the Schengen Agreement's member states pushed Italy to strengthen its borders, which had since become the external 
southern borders of this EUropean space of free circulation. In a context where migration was largely felt as a security issue Italy had no choice, but to adapt. This reveals how the possibilities for an inclusive nation should also be searched away from the nation itself, in the very system of states - what Billig (1995) banally calls 'the world of nations' - which exercises a structural constraint for the nation and its forms.

Domestically, the growing discontent in major Italian cities regarding perceived high levels of immigrants' criminality also contributed to temper the solidarist approach. With the political right capitalizing on citizens' fears towards immigrants, the political left also chose to treat migration in security terms, thus implicitly aligning itself with a more exclusivist understanding of the national collective. Not surprisingly, less than a decade after the approval of Law 40/1998, a new centreleft government adopted the Charter on Citizenship Values and Integration, ${ }^{4}$ which would signal the explicit civic integrationist turn of the Italian political left and, consequently, its more culturalist understanding of the nation (Gargiulo 2014b). This highlights a sort of cross-party ideological convergence - also witnessed elsewhere in Europe (Hinnfors, Spehar, and BuckenKnapp 2012; Jensen and Mouritsen 2015; Alonso and da Fonseca 2012) - which clearly hinders the pluralization of the nation in institutional terms. The persistence of the ethno-cultural core remains at work in the way the state operates, mediating the incorporation of newcomers and producing a hierarchy of national belonging and citizenship rights (Hage 2000), which implicates and is implicated in a conditional idea of plurality and inclusivity. Echoing Mezzadra and Neilson (Mezzadra and Neilson 2012), the inclusive nation then comes to rely on a project of differentiation, where inclusion and exclusion are not clearly and fixedly delineated, but are continuously at work in the production of a form of differentiated and hierarchized inclusion, which again reaffirms the primacy of the ethno-cultural group over the symbolic, legal, and material meaning of nation. 
Our research thus clearly highlights both the international and domestic factors which might condition the transformation of the nation in more inclusive terms, particularly in contexts where immigration continues to be terrain of parties' competition and instrumentalized for political gains both at the EU and at the national levels. However, we should also mention another factor which, while accounting as an additional obstacle to the implementation of an inclusive nation, might equally suggest a possible alternative for actualizing this idea. As discussed earlier in the article, measures aimed at acknowledging and supporting cultural pluralism remained largely on the declaratory level, given the absence of specific national directives and resources. This governance shortcoming, nevertheless, opened the way to local and regional interventions, which were to find official sanction in the 2001 federalist reform (Campomori and Caponio 2013). This is an important point which allows to think of nation beyond the national scale (Jones and Fowler 2007). In other words, the possibilities for generating an inclusive nation should also be searched away from a centralized, normative discourse which aspires to evenly spread across the national space. Recent scholarship (Rossetto 2015; Downing 2015; Wilson 2015) has indeed highlighted the importance of local, urban contexts in generating forms of national inclusion. This is not to say that local instances of nationhood are per se more progressive or less dominated by the ethno-cultural core group than those produced centrally by the state. In the case of Italy, in fact, there is evidence that this might not be the case also in areas traditionally ruled by leftist administrations (Però 2007). Yet, theoretically, it is important to move away from an exclusive conceptualization of the nation at the national scale so to offers more articulated and multiscalar accounts of nationhood. For instance, in the case of the US, Walker (2014) has noted how an inclusive local nation coexists with more exclusive forms, thus producing a fragmented geography of nationhood which questions the unrealistic expectation of a singular national narrative evenly spanning from centre to periphery (Agnew 2013). 
To be clear, we are not arguing here to deflect attention away from national narratives and policies centrally produced. In line with recent scholarship (Bloemraad 2014; Moran 2011), we indeed argue for the continuing importance of the national centre in potentially driving change. Yet, this should not be regarded as the exclusive level of analysis, since the nation cannot be fully grasped at the national scale only. It is instead at the intersection of a plurality of scales, from the local to the national, the supranational and the global, and by attending to the socio-political contingencies of the geographical contexts under investigation that a richer understanding of the limits and possibilities of the inclusive nation can be produced.

\section{References}

Agnew, J. 2013. "Nationalism." In The Wiley-Blackwell Companion to Cultural Geography, edited by N.C. Johnson, R.H. Schein and J. Winders, 130-45. Malden, MA: John Wiley \& Sons.

Alba, R. and N. Foner. 2014. "Comparing Immigrant Integration in North America and Western Europe: How Much Do the Grand Narratives Tell Us?" International Migration Review 48 (s1):S263-S91.

Allievi, S. 2014. "Immigration, religious diversity and recognition of differences: the Italian way to multiculturalism." Identities 21 (6):724-37.

Alonso, S. and S. Claro da Fonseca. 2012. "Immigration, left and right." Party Politics 18 (6):86584.

Antonsich, M. 2009. "National identities in the age of globalization. The case of Western Europe." National Identities 11 (3):281-99. 
Antonsich, M. and T. Matejskova. 2015a. "Conclusion: Nation and diversity - A false conundrum." In Governing Through Diversity, edited by T. Matejskova and M. Antonsich, 201-9. Basingstoke: Palgrave.

Antonsich, M. and T. Matejskova. 2015b. "Immigration societies and the question of 'the National'." Ethnicities 15 (4):495-508.

Banting, K.G. and W. Kymlicka. 2012. Is there really a backlash against multiculturalism policies? New evidence from the multiculturalism policy index. Barcelona: GRITIM Working Paper Series n. 14.

Baumeister, A. 2007. "Diversity and unity. The problem with 'constitutional patriotism'." European Journal of Political Theory 6 (4):483-503.

Bedani, G. and B. Haddock. 2000. The Politics of Italian National Identity. Cardiff: University of Wales Press.

Billig, M. 2017. "Nationalism, exclusion and inclusion." Identities 24 (2):157-61.

Biswas, S. 2002. "W(h)ither the Nation-state? National and State Identity in the Face of Fragmentation and Globalisation." Global Society 16 (2):175-98.

Bloemraad, I. 2014. "Re-imagining the Nation in a World of Migration: Legitimacy, Political Claimsmaking and Membership in Comparative Perspective." In Fear and Anxiety over National Identity, edited by N. Foner and P. Simon, 59-82. New York: Russell Sage Foundation Press. Bonifazi, C., F. Heins, S. Strozza, and M. Vitiello. 2009. The Italian transition from emigration to immigration country. Roma: IRPPS Working paper 24/2009.

Bouchard, G. 2011. "What is interculturalism?" McGill Law Journal 56 (2):435-68.

Brubaker, R. 1999. "The Manichean myth: rethinking the distinction between 'civic' and 'ethnic' nationalism." In Nation and National Identity, edited by H. Kriesi, K. Armingeon, H. Siegrist and A. Wimmer, 55-71. Zürich: Rügger. 
Brubaker, R. 2006. Nationalist politics and everyday ethnicity in a Transy/vanian town. Princeton: Princeton University Press.

Calhoun, C. 2007. Nations matter. London: Routledge.

Campomori, F., and T. Caponio. 2013. "Competing frames of immigrant integration in the EU: geographies of social inclusion in Italian regions." Policy Studies 34 (2):162-79.

Cuttitta, P. 2014. "Mandatory Integration Measures and Differential Inclusion: The Italian Case." Journal of International Migration and Integration, 17(1): 289-302.

Downing, J. 2015. "Understanding the (Re) Definition of Nationhood in French Cities: A Case of Multiple States and Multiple Republics." Studies in Ethnicity and Nationalism 15 (2):33651.

Favell, A. 2001. "Multicultural nation-building: 'Integration' as public philosophy and research paradigm in Western Europe." Swiss Political Science Review 7(2):95-130.

Finotelli, C., and G. Sciortino. 2009. "The importance of being southern: The making of policies of immigration control in Italy." European Journal of Migration and Law 11 (2):119-38.

Galli della Loggia, E. 1996. La morte della patria. Bari: Laterza.

Garau, E. 2014. Politics of National Identity in Italy. London: Routledge.

Gargiulo, E. 2014a. "Dall'inclusione programmata alla selezione degli immigrati: le visioni dell'integrazione nei documenti di programmazione del governo italiano." Polis 27 (2):22150.

Gargiulo, E. 2014b. "Integrazione o esclusione? I meccanismi di selezione dei non cittadini tra livello statale e livello locale." Diritto, immigrazione e cittadinanza 16 (1):41-62.

Gentile, E. 2010. Né stato né nazione. Roma-Bari: Laterza. 
Goodman, S.W. 2010. "Integration requirements for integration's sake? Identifying, categorising and comparing civic integration policies." Journal of Ethnic and Migration Studies 36 (5):753-72.

Graziano, M. 2010. The failure of Italian nationhood. London: Palgrave.

Gustavsson, G. 2015. Liberal national identity: thinner than conservative, thicker than civic-but in terms of what? Paper presented at the ECPR Joint Sessions, Warsaw, March 30th-April 2nd. Habermas, J. 1998. The Inclusion of the Other. Cambridge, Mass: MIT. Habermas, J. 2001. The Postnational Constellation. Cambridge, Mass: MIT. Hage, G. 2000. White nation. London: Routledge.

Hinnfors, J., A.Spehar and G. Bucken-Knapp. 2012. "The missing factor: Why social democracy can lead to restrictive immigration policy." Journal of European Public Policy 19 (4):585-603.

Jensen, K.K. 2014. "What can and cannot be willed: how politicians talk about national identity and immigrants." Nations and Nationalism 20 (3):563-83.

Jensen, K.K., and P. Mouritsen. 2015. "The politics of citizenship education in Denmark." In 43rd ECPR Conference. University of Warsaw: ECPR.

Jessop, B. 1993. "From the Keynesian welfare to the Schumpeterian workfare state." In Towards a Post-Fordist Welfare State?, edited by R. Burrows and B. Loader, 13-37. London: Routledge. Jones, R., and C. Fowler. 2007. "Placing and scaling the nation." Environment and Planning D: Society and Space 25 (2):332-54.

Jones, R., and P. Merriman. 2012. "Network nation." Environment and Planning A 44 (4):937-53. Joppke, C. 2007. "Beyond national models: Civic integration policies for immigrants in Western Europe." West European Politics 30 (1):1-22.

Joppke, C. 2008. "Immigration and the identity of citizenship: The paradox of universalism." Citizenship Studies 12 (6):533-46. 
Joppke, C. 2010. Citizenship and immigration. Cambridge: Polity.

Joppke, C., and E. Morawska. 2003. Toward assimilation and citizenship. New York: Palgrave.

King, R., and Black, R. 1997. Southern Europe and the new immigrations. Brighton: Sussex Academic Press.

Kohn, H. 1945. The Idea of Nationalism. New York: Macmillan.

Kostakopoulou, D. 2010. "The anatomy of civic integration." The Modern Law Review 73 (6):93358.

Kymlicka, W. 2001. Politics in the Vernacular. New York: Oxford University Press.

Kymlicka, W. 2002. Contemporary political philosophy. Oxford: Oxford University Press.

Kymlicka, W. 2015. Building solidarity in diverse societies. Fiesole: European University Institute.

Larner, W. 2000. "Neo-liberalism: Policy, ideology, governmentality." Studies in political economy 63:5-25.

Mezzadra, S., and B. Neilson. 2012. "Between inclusion and exclusion: On the topology of global space and borders." Theory, Culture \& Society 29 (4-5):58-75.

Mezzadra, S., and B. Neilson. 2013. Border as Method. Durham: Duke University Press.

Miller, D. 2000. Citizenship and National Identity. Cambridge: Polity Press.

Modood, T. 2007. Multiculturalism. Cambridge: Polity Press.

Modood, T. 2013. The strange non-death of multiculturalism. Fiesole: EUI.

Moran, A. 2011. "Multiculturalism as nation-building in Australia: Inclusive national identity and the embrace of diversity." Ethnic and Racial Studies 34 (12):2153-72.

Mottura, G. and M. Rinaldini. 2008. "Migrants Regulatory Frameworks. Precariousness as a constant factor." In Refugees, recent migrants and employment, edited by S. McKay, 84101. London: Routledge. 
Mouritsen, P. 2008. "Political responses to cultural conflict: Reflections on the ambiguities of the civic turn." In Constituting communities, edited by P. Mouritsen and K.E. Jørgensen, 1-30. Basingstoke: Palgrave.

Mouritsen, P. and T.V. Olsen. 2013. "Denmark between liberalism and nationalism." Ethnic and Racial Studies 36 (4):691-710.

Muehlebach, A. 2012. The moral neoliberal. Chicago: University of Chicago Press.

Parekh, B. 2000. Rethinking multiculturalism. London: Macmillan.

Pastore, F. 2004. "A community out of balance: nationality law and migration politics in the history of post-unification Italy." Journal of Modern Italian Studies 9 (1):27-48.

Patriarca, S. 2010. Italian Vices. Cambridge: Cambridge University Press.

Peck, J. and A. Tickell. 2002. "Neoliberalizing space." Antipode 34 (3):380-404.

Pensky, M. 2001. "Editor's Introduction." In The Postnational Constellation, by Jürgen Habermas, vii-xvii. Cambridge: MIT Press.

Però, Da. 2005. "Left-wing politics, civil society and immigration in Italy: The case of Bologna." Ethnic and Racial Studies 28 (5):832-58.

Pugliese, E. 2002. L'Italia tra migrazioni internazionali e migrazioni interne. Bologna: il Mulino.

Putnam, R.D. 1993. Making Democracy Work. Princeton: Princeton University Press.

Rossetto, T. 2015. "Performing the nation between us: urban photographic sets with young migrants." Fennia 193 (2):165-84.

Schneider, J. 1998. Italy's 'Southern Question'. Oxford: Berg.

Smith, A.D. 1991. National Identity. London: Penguin Books.

Turco, L., and P. Tavella. 2005. I nuovi italiani. Milano: Mondadori.

Vertovec, S. 2011. "The cultural politics of nation and migration." Annual Review of Anthropology 40:241-56. 
Vertovec, S. and S. Wessendorf. 2010. The Multiculturalism Backlash. New York: Routledge.

Walker, K.E. 2014. "Immigration, local policy, and national identity in the suburban United States." Urban Geography 35 (4):508-29.

Wilson, H.F. 2015. "An urban laboratory for the multicultural nation?" Ethnicities 15 (4):586-604.

Wimmer, A., and N. Glick Schiller. 2002. "Methodological nationalism and beyond: nation-state building, migration and the social sciences." Global Networks 2 (4):301-34.

Zincone, G. 1998. "Illegality, enlightenment and ambiguity: A hot Italian recipe." South European Society and Politics 3 (3):45-82.

Zincone, G. 2000. "A model of "reasonable integration": Summary of the First Report on the Integration of Immigrants in Italy." International Migration Review 34 (3):956-68.

Zincone, G. 2006. "The making of policies: Immigration and immigrants in Italy." Journal of Ethic and Migration Studies 32 (3):347-75.

\footnotetext{
${ }^{1}$ Identification and Expulsion Centers (CIEs) have been created to host undocumented migrants who have received an expulsion order and are waiting to be repatriated.

${ }^{2}$ The integration agreement, to be signed at the moment of the application for permesso di soggiorno, is based on a credit-point system. The non-attainment of the credit threshold may involve the loss of the permesso.

${ }^{3}$ These were the key-words (in Italian): "Immigrazione", "integrazione", "immigrati", "migranti", "straniero", "identità + nazionale", "seconde generazioni", "intercultura", "nuovi italiani", "2G", "figli di migranti", "figli di immigrati", and "cittadinanza".

${ }^{4}$ The Charter's text is available in English: http://www.immigrazioneoggi.it/pubblicazioni/dwnld/cartadeivalori en.pdf
} 